\title{
Rancang Bangun Mesin Pembersih dan Pengupas Kentang
}

\author{
Wahyu. K. Sugandi*, Totok Herwanto, dan Ayuditha Putri Yudi \\ Departemen Teknik Pertanian dan Biosistem, Fakultas Teknologi Industri Pertanian, \\ Universitas Padjadjaran \\ Alamat korespondensi: sugandiwahyu@gmail.com
}

\section{ABSTRACT \\ Engineering of potatoes cleaning and peeling machine}

Chips can be produced from varieties of raw materials including potatoes. To make potato chips on a large scale requires a machine that can facilitate all or one of the manufacturing processes. Therefore, research on the design of potatoes cleaning and peeler machine and its performance tests were required. The research method used was engineering method. The stages of this research were problem identification, data collection, designing, manufacturing and testing machine. This machine consisted of several components, namely frame unit, cleaning unit and peeler, and transmission unit. The mechanism of this machine was to put the water in and then turn on the motor connected to the brush and put the potato in. The potato will rotate and will hit the brush so that the skin peeled off. When the motor turned off, the faucet can be opened to remove the water. The lid on the tube can be opened to take the potato out. The engine design have a total dimension (1000 x $400 \times 400) \mathrm{mm}$, height and diameter of the tube of $330 \mathrm{~mm}$ and $380 \mathrm{~mm}$, using two cleaning brushes on one axis. with theoretical capacity of $152 \mathrm{~kg} /$ hour, actual capacity of 60 $\mathrm{kg} /$ hour.

Keywords: cleaning and peeler machine, potato, cleaning brush

\begin{abstract}
ABSTRAK
Keripik dapat diproduksi dari berbagai macam bahan baku diantaranya kentang. Untuk membuat keripik kentang dalam skala yang besar dibutuhkan sebuah mesin yang dapat memudahkan semua atau salah satu proses pembuatannya. Oleh karena itu dibutuhkan penelitian mengenai rancang bangun mesin pembersih dan pengupas kentang serta uji kinerja mesin tersebut. Metode penelitian yang digunakan yaitu metode rekayasa. Tahapan penelitian ini yaitu identifikasi masalah, pengumpulan data, perancangan, pembuatan dan pengujian mesin. Mesin ini terdiri dari beberapa komponen yaitu unit rangka, unit pembersih dan pengupas, dan unit transmisi. Mekanisme kerja dari mesin ini yaitu memasukkan air lalu menyalakan motor yang terhubung dengan sikat lalu memasukkan kentang dimana kentang itu akan beruputar dan akan mengenai sikat sehingga kulit terkupas lalu motor dimatikan. Kran dapat dibuka sehingga air akan keluar, lalu jika tutup pada tabung dibuka, kentang dapat keluar. Hasil dari rancang bangun mesin memiliki total dimensi $(1000 \times 400 \times 400) \mathrm{mm}$, tinggi dan diameter tabung masing-masing adalah $330 \mathrm{~mm}$ dan $380 \mathrm{~mm}$, menggunakan dua buah sikat pembersih pada satu poros dengan kapasitas teoritis sebesar 152 $\mathrm{kg} / \mathrm{jam}$, kapasitas aktual sebesar $60 \mathrm{~kg} / \mathrm{jam}$,
\end{abstract}

Kata kunci: Mesin pembersih, mesin pengupas kentang, sikat pembersih 


\section{PENDAHULUAN}

Saat ini potensi di bidang pertanian menjadi salah satu aspek yang harus diprioritaskan dan menjadi peluang usaha yang baik bagi pembangunan nasional. Misalnya dengan mengolah umbi-umbian menjadi berbagai macam makanan ringan maupun berat yang mempunyai rasa khas dan tahan lama untuk disimpan. Bentuk olahan tersebut bisa berupa tepung, gaplek, tape, keripik dan yang lainnya Makanan ringan atau snack telah berkembang dengan pesat baik dari jenis, cita rasa maupun kemasannya. Salah satu jenis makanan yang mempunyai prospek yang baik untuk kedepannya yaitu keripik. Produk makanan ringan dalam perkembangannya dapat diproduksi dari berbagai macam bahan baku diantaranya makanan ringan berbahan baku kentang.

Untuk membuat keripik kentang dalam skala yang besar maka dibutuhkan sebuah alat atau mesin yang dapat membantu memudahkan semua atau salah satu dari proses pembuatan keripik kentang tersebut. Di Desa Cikajang, Kecamatan Cikajang, Garut terdapat salah satu UKM yang dianggap maju atau berkembang yaitu PD Intan Mandiri yang memproduksi 1 ton keripik kentang perminggu dimana pada 1 ton kentang bisa menjadi $300 \mathrm{~kg}$ keripik kentang. Proses yang dilakukan untuk membuat keripik kentang adalah sebagai berikut: pertama mengupas kulit kentang, lalu yang kedua melakukan pencucian sampai kentang tersebut bersih, setelah itu melalukan pengirisan sesuai bentuk dan ukuran yang diinginkan, lalu yang terakhir melakukan penggorengan. Pada UKM PD Intan Mandiri proses membuat keripik kentang tersebut sudah menggunakan mesin pada bagian proses pengupasan kentang. Mesin pengupas yang dimiliki oleh UKM tersebut berkapasitas $120 \mathrm{~kg} / \mathrm{jam}$ dimana pada proses pengeluaran bahan yaitu kentang masih menggunakan tangan untuk membantu pengeluran kentang yang sudah dikupas. Hasil dari pengupasan yang dilakukan dengan mesin tersebut masih kurang maksimal dikarenakan masih terdapat kulit-kulit kentang yang tidak terkupas dan ada daging kentang yang ikut terkikis.

Seiring berjalannya waktu permintaan pasar terhadap keripik kentang pada saat ini semakin meningkat yaitu mencapai 1,3 ton keripik kentang/minggu dimana kentang yang dibutuhkan sebanyak 4,5 ton kentang perminggu. Oleh sebab itu, dibutuhkan suatu penelitian berkenaan dengan teknologi mesin yang dapat membersihkan dan mengupas kentang dengan kapasitas lebih besar, hasil yang lebih baik atau kulit kentang yang tersisa pada kentang lebih sedikit dan dapat dikeluarkan dengan cara yang lebih praktis.

\section{METODE PENELITIAN}

Metode penelitian yang digunakan dalam penelitian ini adalah metode rekayasa (engineering). Menurut Stefanus (2005), metode rakayasa (engineering) adalah melakukan sesutau kegiatan rencana (plan), perancangan (design), konstruksi (construct), terapan (applied) yang tidak rutin, sehingga di dalamnya terdapat suatu modifikasi dan kontribusi baru, baik dalam bentuk proses maupun produk. Penelitian dengan menggunakan metode rekayasa ini terdiri dari beberapa tahap. Tahapan tersebut dapat dilihat pada Gambar 1.

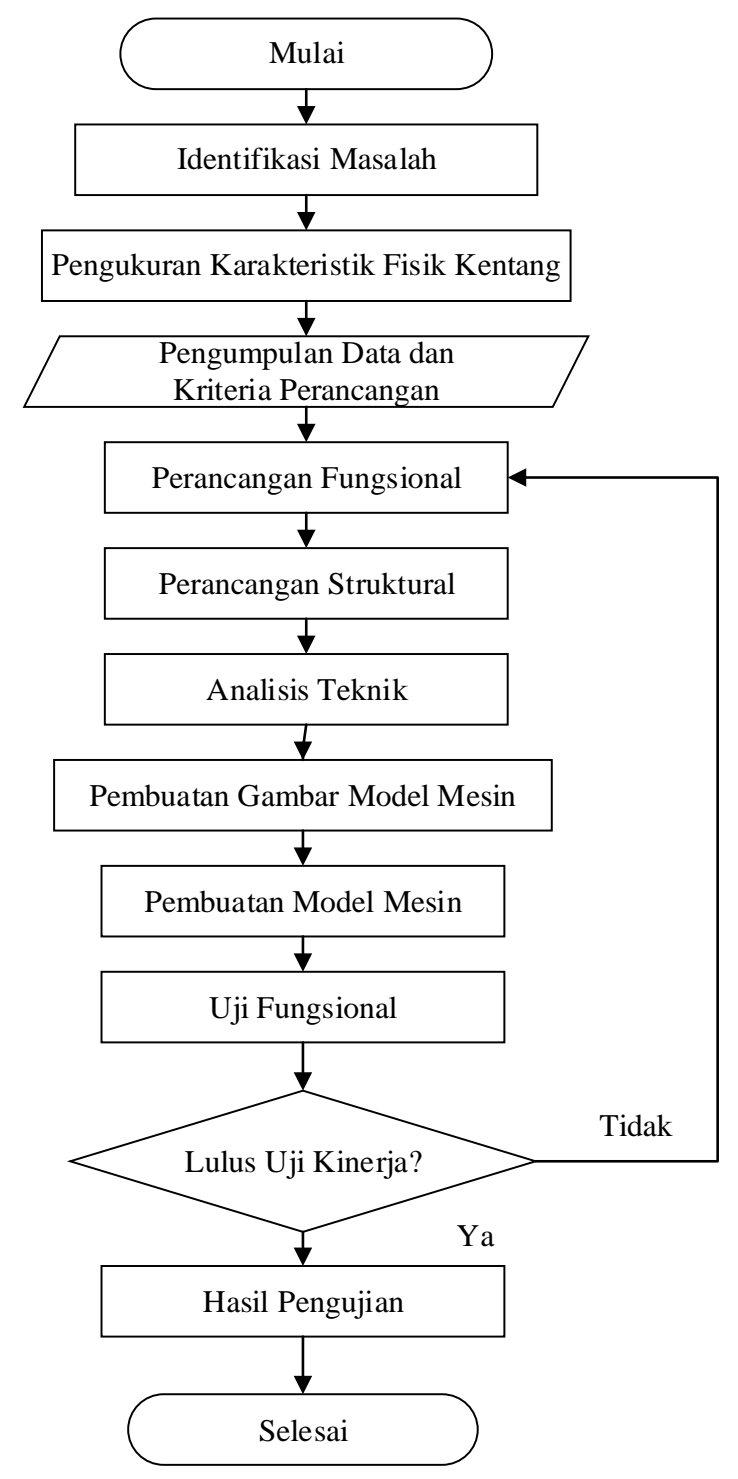

Gambar 1. Tahapan perakitan mesin pembersih dan pengupas kentang. 


\section{PERANCANGAN}

\section{Kriteria Perancangan}

Menurut Harsokoesoemo (1999), perancangan (design) adalah kegiatan awal dari usaha merealisasikan suatu produk yang keberadaanya dibutuhkan oleh masyarakat untuk meringankan hidupnya. Pada mesin pembersih dan pengupas yang akan dibangun ini diharapkan dapat memenuhi kriteria sebagai berikut:

a. Dapat menghilangkan kulit dan kotoran yang berada pada kentang semaksimal mungkin.

b. Dapat membersihkan kentang dengan kapasitas $152 \mathrm{~kg} / \mathrm{jam}$.

c. Terdapat pintu keluar kentang pada bagian bawah tabung/wadah.

d. Terdapat keran untuk mengeluarkan air.

e. Sistem pembersihan dan pengupasan menggunakan sikat yang berputar.

f. Penggerak mesin menggunakan motor listrik.

g. Sistem transmisi menggunakan puli dan sabuk.

\section{Mekanisme Kerja}

Mekanisme kerja dari mesin pembersih dan pengupas kentang ini yaitu dimulai dengan mengisi air pada wadah pembersih dan pengupas Lalu menyalakan motor dimana motor tersebut tersambung pada sabuk dan puli yang dapat menggerakkan sikat pembersih kentang. Setelah itu air yang di dalam wadah berputar. Ketika kentang sebanyak $5 \mathrm{~kg}$ dimasukkan, kentang tersebut akan berputar dan akan mengenai sikat sehingga kulit kentang akan terkupas. Setelah itu motor dimatikan dan keran yang ada dibawah wadah dibuka sehingga air pada wadah tersebut habis. Kemudian pada bagian bawah wadah terdapat pintu sehingga kentang yang sudah bersih akan turun.

\section{Rancangan Fungsional}

Rancangan fungsional adalah hasil desain suatu komponen dari sistem yang memiliki fungsi saling mendukung untuk menjalankan sistem tersebut. Rancangan fungsional pada mesin pembersih dan pengupas yaitu sebagai berikut:

a. Rangka Mesin: berfungsi untuk menahan beban berat komponen utama dari mesin.

b. Kran: berfungsi untuk mengeluarkan air.

c. Pintu Keluar: tempat dimana bahan yang sudah bersih keluar dari dalam tabung.

d. Tabung: tempat untuk membersihkan dan mengupas kentang.

e. Sikat Pembersih: alat berfungsi untuk membersihkan dan mengupas kentang. f. Sistem Transmisi: Untuk menggerakkan sikat pembersih dari puli yang disambungkan menggunakan sabuk-v.

g. Motor: Untuk menggerakkan sikat pembersih.

\section{Rancangan Struktural}

Rancangan struktural dilakukan untuk menentukan komponen dan struktur dari desain mesin yang akan direalisasikan sesuai dengan kriteria untuk menghasilkan kentang yang bersih secara optimal.

a) Rangka: bahan yang akan digunakan pada rangka yaitu besi siku. Rangka pada mesin pembersih dan pengupas kentang ini memiliki dimensi $400 \mathrm{x} 400 \mathrm{x}$ $550 \mathrm{~mm}$ (Gambar 2).

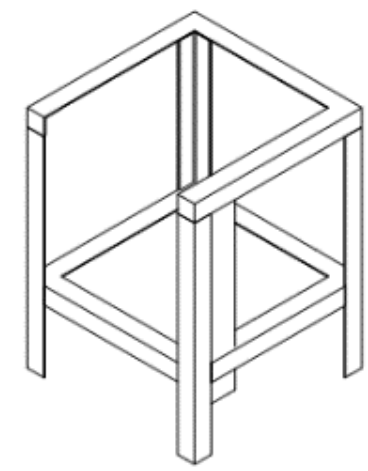

Gambar 2. Rangka

b) Tabung: pada perhitungan tabung mesin memiliki dimensi tinggi $330 \mathrm{~mm}$ dengan diameter $356 \mathrm{~mm}$. Bahan yang digunakan tabung ini yaitu plat besi. Pada bagian tabung ini terdapat pintu yang dapat dibuka untuk mengeluarkan kentang dengan panjang dan lebar 60 x 60 mm (Gambar 3).

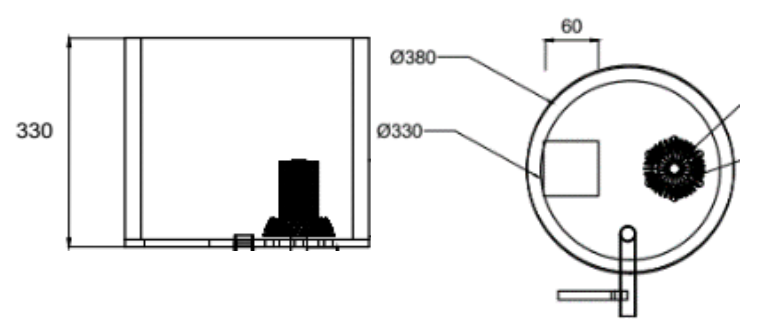

Gambar 3. Tabung

c) Sikat Pembersih: terdapat bulu sikat yang terbuat dari nylon tipe 6.12. Jenis bulu sikat nylon tersebut dipilih karena bahan tersebut tidak mudah menyerap air dan bahan nylon tipe tersebut sangat tepat untuk digunakan pada proses pengolahan pangan dikarenakan bahan nylon tersebut dapat mencegah pertumbuhan bakteri dan jamur. Panjang 
dari pembersih ini sebesar $135 \mathrm{~mm}$ dengan diameter $100 \mathrm{~mm}$ dan $40 \mathrm{~mm}$ (Gambar 4).

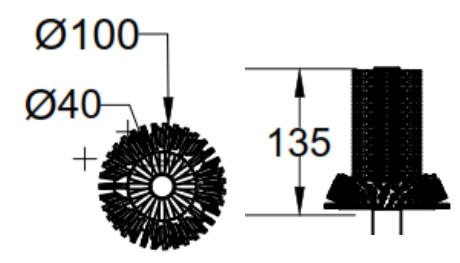

Gambar 4. Sikat pembersih.

d) Sistem Transmsi: yang digunakan pada mesin ini yaitu puli dan sabuk dimana terdapat 2 buah puli dan 1 buah sabuk-v (Gambar 30). Sabuk tersebut menghubungkan puli yang berada di motor ke puli yang berada di poros sikat. Dengan ukuran diameter puli pada motor sebesar $76,2 \mathrm{~mm}$ dan diameter puli pada poros sikat pembersih sebesar $127 \mathrm{~mm}$. Jarak antara puli yaitu $110 \mathrm{~mm}$. sabuk yang digunakan pada mesin ini yaitu jenis sabuk- $\mathrm{v}$ tipe A (Gambar $5)$.

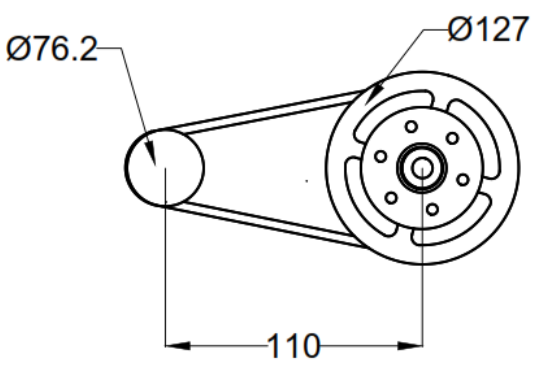

Gambar 5. Sabuk dan puli.

\section{Analisis Teknik}

Menurut Sularso (1997), analisis teknik adalah analisis yang ditujukan untuk mengetahui kekuatan bahan dari setiap komponen mesin yang dilakukan dengan cara melakukan perhitungan secara teoritis dan pengamatan langsung yang terjadi di lapangan.

a) Kebutuhan Daya: Analisis dilakukan untuk mengetahui daya yang diperlukan oleh mesin dalam menjalankan mesin dari awal hingga akhir baik penggerak transmisi, putaran silinder dan lain-lain (Singer dkk, 1995). Perhitungan kebutuhan daya sikat dapat dihitung dengan persamaan berikut:

$$
\mathrm{P}=\frac{2 \pi \times \mathrm{M}_{\mathrm{t}} \times \mathrm{n}}{60}
$$

Dimana:

$\mathrm{P}$ = Daya yang dibutuhkan motor penggerak (W)

$\mathrm{n} \quad=$ Kecepatan putaran puli $(\mathrm{rpm})$

$\mathrm{M}_{\mathrm{t}}=$ Momen puntir $(\mathrm{Nm})$ b) Analisis unit transmisi: bertujuan untuk mengetahui dan menentukan jumlah sabuk dan puli yang diperlukan dalam transmisi mesin. Dalam menentukan panjang sabuk yang digunakan dapat dihitung dengan menggunakan Persamaan (Sularso dan Suga, 1997):

$$
L=2 C+\frac{\pi}{2}\left(D_{p}+d_{p}\right)+\frac{1}{4 C}\left(D_{p}-d_{p}\right)^{2}
$$

Dimana:

$\mathrm{L} \quad=$ Panjang sabuk $(\mathrm{m})$

$\mathrm{C}=$ Jarak antar dua sumbu poros $(\mathrm{m})$

$\mathrm{D}_{\mathrm{p}}=$ Diameter puli besar $(\mathrm{m})$

$\mathrm{d}_{\mathrm{p}}=$ Diameter puli kecil $(\mathrm{m})$

Sudut kontak sabuk dapat dihitung dengan menggunakan Persamaan (Hall et. al. 1993):

Dimana:

$$
\alpha_{1}=180 \pm 2 \cdot \arcsin \left(\frac{\mathrm{R}-\mathrm{r}}{\mathrm{C}}\right)
$$

$$
\begin{array}{ll}
\alpha_{1} & =\text { Sudut kontak sabuk } \\
\mathrm{R} & =\text { Jari-jari puli besar }(\mathrm{m}) \\
\mathrm{r} & =\text { Jari-jari puli kecil }(\mathrm{m})
\end{array}
$$

Bila sabuk-V bekerja meneruskan momen, tegangan akan bertambah pada sisi tarik $\mathrm{T}_{1}$ (bagian panjang sabuk yang menarik) dan berkurang pada sisi kendor $T_{2}$ (bagian panjang sabuk yang tidak menarik) dapat dihitung dengan Persamaan (Sularso \& Suga, 1997):

Dimana:

$$
\mathrm{T}_{1}=\sigma_{\mathrm{a}} \times \mathrm{A}
$$

$\mathrm{T}_{1}$ = Tegangan pada sisi kencang $(\mathrm{N})$

$\sigma_{\mathrm{a}}=$ Tegangan sabuk yang diijinkan (MPa)

$\mathrm{A}=$ Luas penampang sabuk $\left(\mathrm{m}^{2}\right)$

Sementara tegangan sisi kendor $\mathrm{T}_{2}$ dapat dihitung dengan mengunakan Persamaan (Sularso \& Suga, 1997):

$$
\frac{\mathrm{T}_{1}-\mathrm{m}_{\mathrm{s}} \cdot \mathrm{v}^{2}}{\mathrm{~T}_{2}-\mathrm{m}_{\mathrm{s}} \cdot \mathrm{v}^{2}}=\mathrm{e}^{\alpha . \mathrm{f} / \sin \frac{\theta}{2}}
$$

Dimana:

$\mathrm{T}_{2} \quad$ = Tegangan pada sisi kendor $(\mathrm{N})$

$\mathrm{m}_{\mathrm{s}} \quad=$ Massa sabuk $(\mathrm{kg})$

$\mathrm{v} \quad=$ Kecepatan linier $(\mathrm{m} / \mathrm{s})$

Kecepatan linier dapat dihitung dengan mengunakan Persamaan (Sularso dan Suga, 1997):

$$
\mathrm{v}=\frac{2 \pi \times \mathrm{d}_{\mathrm{m}} \times \mathrm{N}}{60}
$$

Dimana:

$$
\begin{aligned}
V & =\text { Kecepatan linier sabuk }(\mathrm{m} / \mathrm{s}) \\
\mathrm{d} \mathrm{m} & =\text { Diameter puli motor penggerak }(\mathrm{m})
\end{aligned}
$$$$
\mathrm{N}=\text { Kecepatan putaran puli (rpm) }
$$ 
Besarnya daya persabuk dapat ditentukan dengan menggunakan Persamaan (Hall et. al. 1993):

Dimana:

$$
P_{s}=\left(T_{1}-T_{2}\right) \times v
$$

$\mathrm{P}_{\mathrm{s}}$ = Daya per sabuk (watt/sabuk)

Jumlah sabuk yang digunakan dapat dihitung dengan menggunakan Persamaan (Sularso dan Suga, 1997):

Dimana:

$$
n_{s}=\frac{P_{t}}{P_{s}}
$$

$\mathrm{n}_{\mathrm{s}}=$ Jumlah sabuk

$\mathrm{P}_{\mathrm{t}}=$ Daya yang tersedia $(\mathrm{W})$

$\mathrm{P}_{\mathrm{s}}$ = Daya yang ditransmisikan per sabuk (W)

c) Analisis Poros: Menurut Khurmi \& Gupta (2008), Poros berfungsi untuk menyalurkan tenaga mekanik dari atu elemen mesin ke elemen mesin yang lainnya. Menurut Hall, et. al. (1983) perhitungan poros dengan beban puntir murni atau punter lentur dengan beban aksial dapat dihitung menggunakan sebagai berikut:

$$
\mathrm{d}^{3}=\frac{16}{\pi \cdot S s\left(1-\mathrm{K}^{4}\right)} \sqrt{\left[\mathrm{KbMb}+\frac{\alpha \cdot \mathrm{F}_{\mathrm{a}} \cdot \mathrm{d}_{0}\left(1-\mathrm{K}^{4}\right)}{8}\right]^{2}+\left(\mathrm{K}_{\mathrm{t}} \mathrm{M}_{\mathrm{t}}\right)^{2}}
$$

Dimana:

$$
\begin{array}{ll}
\mathrm{d}_{0} & =\text { Diameter luar poros }(\mathrm{m}) \\
\mathrm{d}_{\mathrm{i}} & =\text { Diameter dalam poros }(\mathrm{m}) \\
\mathrm{Kb} & =\text { Faktor koreksi momen lentur } \\
\mathrm{Kt} & =\text { Faktor koreksi momen punter } \\
\mathrm{Mb} & =\text { Momen lentur }(\mathrm{Nm}) \\
\mathrm{Mt} & =\text { Momen puntir }(\mathrm{Nm}) \\
\mathrm{Ss} & =\text { Tegangan geser yang diizinkan }\left(\mathrm{N} / \mathrm{m}^{2}\right) \\
\mathrm{Fa} & =\text { Gaya aksial }(\mathrm{N}) \\
\propto & =\text { Faktor aksi kolom } \\
\mathrm{K} & =\frac{d_{i}}{d_{o}}
\end{array}
$$

d) Analisis Bantalan: Menurut Sularso \& Suga (1997), bantalan adalah elemen mesin yang menumpu poros berbeban, sehingga putaran atau gerakan bolak-baliknya dapat berlangsung secara halus, aman, dan panjang waktu pakainya. Perhitungan berikut ini dapat digunakan untuk mengetahui umur teknis bantalan.

Faktor kecepatan untuk bantalan bola, $f_{n}$

$$
f_{n=}\left(\frac{33,3}{n}\right)^{1 / 3}
$$

Dimana $\mathrm{n}$ adalah putaran poros.
Faktor umur bantalan $f_{h}$

$$
\mathrm{f}_{\mathrm{h}}=\mathrm{f}_{\mathrm{n}} \frac{\mathrm{c}}{\mathrm{W}}
$$

Dimana:

$\mathrm{C}=$ beban nominal dinamis spesifikasi $(\mathrm{kg})$

$\mathrm{W}=$ beban ekuivalen $(\mathrm{kg})$

Umur nominal, $L_{h}$ (juta putaran)

$$
\mathrm{L}_{\mathrm{h}}=500 . \mathrm{f}_{\mathrm{h}}^{3}
$$

e) Analisis Spi: Spi digunakan untuk mencegah terjadinya slip pada putaran puli. Momen torsi pada spi dapat dihitung dengan Persamaan:

$$
\mathrm{M}_{\mathrm{ts}}=\left(\mathrm{T}_{1}-\mathrm{T}_{2}\right) \cdot \mathrm{r}
$$

Dimana:

$\mathrm{M}_{\mathrm{ts}}=$ Momen torsi $(\mathrm{Nm})$

$\mathrm{T}_{1}=$ Tegangan sisi kencang pada sabuk dan puli $(\mathrm{N})$

$\mathrm{T}_{2}=$ Tegangan sisi kendor pada sabuk dan puli $(\mathrm{N})$

$r \quad=$ jari-jari puli $(\mathrm{m})$

Gaya tangensial yang bekerja pada spi yang terletak pada komponen elemen-elemen mesin dapat dihitung dengan menggunakan Persamaan (Hall et al., 1993):

$$
\mathrm{Fs}=\frac{\mathrm{M}_{\mathrm{ts}}}{\mathrm{r}}
$$

Dimana:

$$
\begin{aligned}
& \mathrm{F}_{\mathrm{s}}=\text { Gaya tangensial }(\mathrm{N}) \\
& \mathrm{M}_{\mathrm{ts}}=\text { Momen torsi }(\mathrm{Nm}) \\
& \mathrm{r} \quad=\text { Jari-jari poros }(\mathrm{m})
\end{aligned}
$$

Untuk menghitung ukuran spi yang digunakan berlaku Persamaan (Shigley, 1986):

$$
\begin{gathered}
\mathrm{F}=\tau_{\mathrm{a}} \times \mathrm{A} \\
\mathrm{A}=\frac{\mathrm{F}}{\tau_{\mathrm{a}}}
\end{gathered}
$$

Dimana:

$$
\begin{aligned}
& \mathrm{A}=\text { Luas Spi, } 1 \times \mathrm{t}\left(\mathrm{m}^{2}\right) \\
& \mathrm{F}=\text { Gaya }(\mathrm{N}) \\
& \tau_{\mathrm{a}}=\text { Allowable shear stress }(\mathrm{MPa})
\end{aligned}
$$

Pada spi dapat terjadi gaya geser pada penampang b x 1 karena adanya gaya $F(N)$ dengan demikian tegangan geser spi dapat dihitung berdasarkan Persamaan (Sularso \& Suga, 1997):

Dimana:

$$
\tau_{\mathrm{k}}=\frac{\mathrm{F}}{\mathrm{b} . \mathrm{l}}
$$

$$
\begin{aligned}
\tau_{\mathrm{k}} & =\text { Tegangan geser }\left(\mathrm{N} / \mathrm{m}^{2}\right) \\
\mathrm{F} & =\text { Gaya tangensial }(\mathrm{N}) \\
\mathrm{b} & =\text { lebar spi }(\mathrm{m}) \\
\mathrm{l} & =\text { panjang spi }(\mathrm{m})
\end{aligned}
$$


Kemudian dibandingkan dengan tegangan geser yang diizinkan dihitung dengan menggunakan Persamaan:

$$
\tau_{\mathrm{ka}}=\frac{\sigma}{\mathrm{Sf}_{\mathrm{k} 1} \cdot \mathrm{Sf}_{\mathrm{k} 2}}
$$

Dimana:

$\tau_{\mathrm{ka}}=$ Tegangan geser yang diizinkan $\left(\mathrm{N} / \mathrm{m}^{2}\right)$

$\sigma \quad=$ Kekuatan tarik bahan $\left(\mathrm{N} / \mathrm{m}^{2}\right)$

$\mathrm{Sf}_{\mathrm{k} 1}=$ Faktor keamanan, umumnya bernilai 6

$\mathrm{Sf}_{\mathrm{k} 2}=$ Faktor keamanan, 1-1,5 untuk beban perlahan, 1,5-3 untuk tumbukan ringan, 3-5 untuk tumbukan berat.

f) Analisis Rangka: dihitung berdasarkan lendutan dan beban kritis yang diizinkan. Beban yang dapat ditopang oleh baris menggunakan persamaan berikut (Singer dkk., 1995):

Dimana:

$$
\delta=\frac{\mathrm{PL}^{3}}{48 \mathrm{EI}}
$$

$\delta$ = lendutan yang diizinkan $(\mathrm{m})$
$\mathrm{P}=$ Beban yang bekerja pada rangka $(\mathrm{kg})$

$\mathrm{L}=$ Panjang kolom baris $(\mathrm{m})$

$\mathrm{E}=$ Modulus elastisitas rangka $\left(\mathrm{kg} / \mathrm{m}^{2}\right)$

$\mathrm{I}=$ Momen inersia rangka $\left(\mathrm{m}^{4}\right)$

Kemudian lendutan yang terjadi akibat dari beban yang ditopang oleh rangka dibandingkan dengan lendutan izin menggunakan Persamaan (Singer dkk.,1995):

$$
\delta=\frac{1}{300} \mathrm{~L}
$$

Dimana:

$$
\begin{array}{ll}
\delta & =\text { lendutan yang diizinkan }(\mathrm{m}) \\
\mathrm{L} & =\text { Panjang kolom baris }(\mathrm{m})
\end{array}
$$

\section{HASIL DAN PEMBAHASAN}

Mesin pembersih dan pengupas kentang ini tersusun dari beberapa komponen yaitu unit rangka,

\begin{tabular}{|c|c|c|}
\hline No. & Nama Komponen & Spesifikasi \\
\hline 1. & Kapasitas Aktual & $100 \mathrm{~kg} / \mathrm{jam}$ \\
\hline \multirow[t]{4}{*}{2.} & Dimensi Keselurahan & \\
\hline & Panjang & $400 \mathrm{~mm}$ \\
\hline & Lebar & $400 \mathrm{~mm}$ \\
\hline & Tinggi & $1000 \mathrm{~mm}$ \\
\hline \multirow[t]{4}{*}{3.} & Tenaga Penggerak & \\
\hline & Jenis Motor & Motor Listrik, 1 Fasa \\
\hline & Daya & $1 \mathrm{HP}$ \\
\hline & Kecepatan Putar & $3000 \mathrm{rpm}$ \\
\hline \multirow[t]{6}{*}{4.} & Sistem Transmisi & \\
\hline & Puli & $\varnothing=127 \mathrm{~mm}$ \\
\hline & & Tipe A \\
\hline & Sabuk & $\varnothing=250 \mathrm{~mm}, \mathrm{p}=320 \mathrm{~mm}$ \\
\hline & Poros & $\varnothing=100 \mathrm{~mm}, \mathrm{t}=35 \mathrm{~mm}$ \\
\hline & Sikat & $\varnothing=40 \mathrm{~mm}, \mathrm{p}=100 \mathrm{~mm}$ \\
\hline 5. & Bantalan & 6705 ZZ NTN \\
\hline 6. & Keran & $\varnothing=25 \mathrm{~mm}$ \\
\hline 7. & Tempat Keluar Kentang & $\mathrm{P}=205 \mathrm{~mm}, \mathrm{l}=202 \mathrm{~mm}$, sudut $=60^{\circ}$ \\
\hline \multirow[t]{5}{*}{8.} & Rangka & \\
\hline & Jenis Besi & Besi U (77x40x3) mm \\
\hline & Panjang Rangka & $400 \mathrm{~mm}$ \\
\hline & Tinggi Rangka & $1000 \mathrm{~mm}$ \\
\hline & Lebar Rangka & $400 \mathrm{~mm}$ \\
\hline \multirow[t]{3}{*}{9.} & Roda & 2 sendi mati memiliki rem, 2 sendi berputar memiliki rem \\
\hline & Diameter & 3 inchi \\
\hline & kuantitas & 4 unit \\
\hline
\end{tabular}
unit transmisi, unit ruang pengupas. Untuk melihat spesifikasi dari mesin pembersih dan pengupas kentang dapat dilihat pada Tabel 1.

Tabel 1. Spesifikasi mesin pembersih dan pengupas kentang. 


\section{Komponen Penyusun Mesin Pembersih dan Pengupas Kentang}

a) Motor Listrik: yang digunakan pada mesin ini yaitu motor listrik $1 \mathrm{HP}, 1$ fasa dan memiliki kecepatan putar $3000 \mathrm{rpm}$. Sistem transmisi pada mesin pembersih dan pengupas kentang menggunakan puli. Puli yang digunakan pada mesin ini berdiameter 76,22 mm dengan sabuk-v tipe A. Jarak antara puli pada motor dengan puli pada poros sikat pembersih yaitu $110 \mathrm{~mm}$.

b) Poros: berdasarkan perhitungan secara teoritis didapatkan hasil minimal berdiameter $17 \mathrm{~mm}$, sedangkan diameter poros yang digunakan pada saat pembutan mesin yaitu sebesar $25 \mathrm{~mm}$. Poros yang digunakan oleh mesin ini layak untuk digunakan karena ukuran diameternya lebih besar dari ukuran diameter yang minimal.

c) Bearing: Mesin pembersih dan pengupas kentang ini menggunakan bantalan tipe 6205 ZZ NTN. Berdasarkan perhitungan teoritis, diperoleh umur nominal bantalan sebesar 5945,689 jam, menurut Sularso \& Suga (1997) syarat umur bantalan mesin pertanian minimal 3000 jam, sehingga bantalan pada mesin pembersih dan pengupas kentang ini layak untuk digunakan

d) Sikat: pada mesin ini terdapat dua yang pertama berbentuk setengah lingkaran dimana diameter paling besarnya sebesar $100 \mathrm{~mm}$ dengan tinggi 35 mm seperti pada Gambar 6a. Sedangkan pada sikat yang kedua berbentuk seperti tabung dimana ukuran diameternya sebesar $40 \mathrm{~mm}$ dengan tinggi $100 \mathrm{~mm}$ seperti pada Gambar 6b.

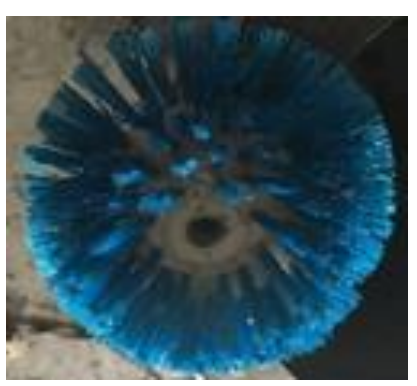

a

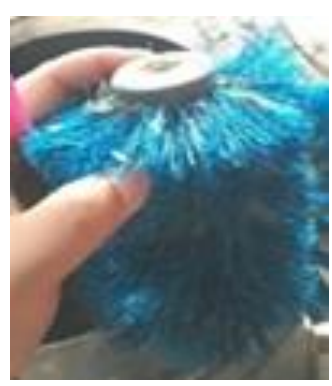

b
Gambar 7. Sikat pembersih.

e) Tabung: berdasarkan perhitungan teoritis dimensi tabung didapatkan hasil diameter sebesar $356 \mathrm{~mm}$ dengan tinggi sebesar $330 \mathrm{~mm}$. Namun pada saat pembuatan diameternya ditambah menjadi $380 \mathrm{~mm}$. Penambahan diameter tersebut dikarenakan agar luas area kentang berputar lebih besar sehingga tidak bertumpukkan karena jika bertumpukan perputaran kentang tersebut menjadi lebih sulit. Di dalam tabung tersebut juga terdapat lubang untuk mengeluarkan air dengan ukuran $25 \mathrm{~mm}$. Selain lubang untuk air di dalam tabung juga terdapat pintu keluar dimana memiliki ukuran sebesar 150 x 95 $\mathrm{mm}$.

f) Rangka: memiliki ukuran $400 \mathrm{~mm}$ (p) x $400 \mathrm{~mm}$ (l) x $550 \mathrm{~mm}$ (t). Tinggi rangka didapatkan dari faktor anthropometri yaitu dari data tinggi siku pada pria di Indonesia sebesar $1003 \mathrm{~mm}$ sehingga hasil dari tinggi keseluruhan mesin didapatkan sebesar $1000 \mathrm{~mm}$ perbandingan tinggi operator dengan tinggi mesin dapat dilihat pada Gambar 7 . Berdasarkan hasil perhitungan lendutan rangka yang didapatkan yaitu sebesar 0,000013 m.

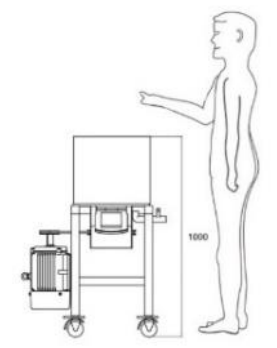

Gambar 7. Perbandingan Tinggi

g) Roda: roda pada mesin pembersih dan pengupas kentang ini berukuran 3 inci. Roda yang digunakan sebanyak 4 buah roda dimana ada 2 jenis roda yang berbeda yaitu 2 roda jenis dinamis dan 2 roda jenis tipe sendi mati.

Pada proses rancang bangun mesin pembersih dan pengupas kentang, langkah pertama yang dilakukan adalah perancangan mesin. Perancangan mesin ini yaitu gambar teknik rancangan mesin dalam bentuk CAD yang selanjutnya dilakukan proses pembuatan mesin.

Proses pembuatan mesin pembersih dan pengupas dilakukan di Surya Teknik Utama Lingkungan Industri Kecil Gedebage Bandung. Sedangkan pegujian mesin pembersih dan pengupas kentang dilakukan di Bengkel Logam, Kayu dan Rotan, Departemen Teknik Pertanian dan Biosistem Fakultas Teknologi Industri Pertanian, Universitas Padjadjaran.

Mesin pembersih dan pengupas kentang dibuat sesuai dengan fungsi dan struktur yang terdapat pada perancangan. Akan tetapi pada saat pembuatan mengalami beberapa perbaikan. Perbaikan ini yaitu pada bagian tabung diameternya 
diperbaiki menjadi $380 \mathrm{~mm}$ dimana pada perhitungan teoritis didapatkan hasil sebesar 356 mm. Perbaikan tersebut dikarenakan agar area perputaran kentang lebih besar. Secara fungsional mesin pembersih dan pengupas kentang ini sudah dapat berfungsi. Secara struktural, mesin pembersih dan pengupas kentang ini seperti pada Gambar 8 .

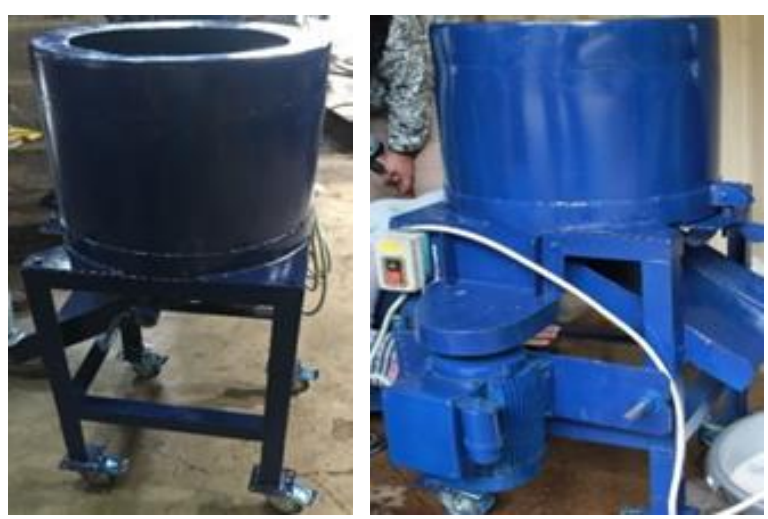

Gambar 8. Mesin pembersih kentang.

\section{Pengujian Fungsional Mesin Pembersih dan Pengupas Kentang}

Tujuan dilakukannya uji fungsional adalah untuk melihat fungsi mesin dari hasil rancang bangun yang telah dibuat. Hasil dari pengujian diperoleh bahwa mesin dapat bekerja sesuai dengan tujuan awal yaitu dapat membersihkan dan mengupas kentang seperti kriteria perancangan yang telah ditentukan sebelumnya.
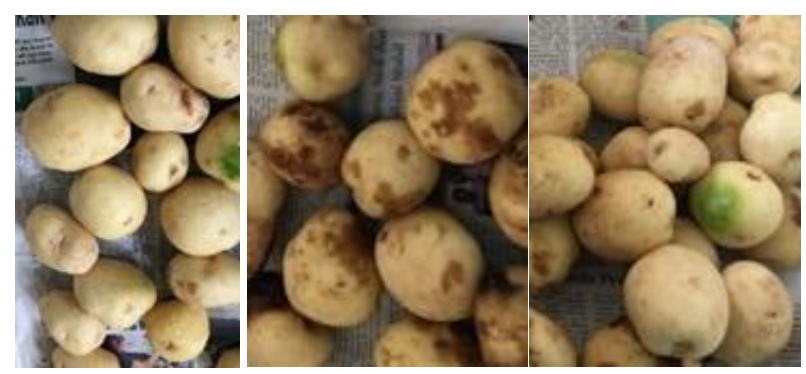

Gambar 9. Kentang hasil pengupasan

Pada proses pembersih dan pengupas ini terdapat beberapa komponen yang mendukung terjadinya proses pengupasan yaitu unit pembersih dan pengupas, dan sistem transmisi. Setiap komponen tersebut bekerja sesuai fungsinya masingmasing. Setelah proses pembersihan dan pengupasan, dilakukan pengukuran massa dari tiga macam jenis kulit yang tersisa yaitu tidak ada kulit yang tersisa (Gambar 9a), kulit yang tersisa kurang dari 1/4 (Gambar 9b) dan kulit yang tersisa lebih dari 1/4 (Gambar 9c). Dari hasil pengamatan tersebut didapatkan hasil rata-rata persentase dari tidak adanya kulit yang tersisa yaitu sebesar $44 \%$, untuk kulit yang tersisa kurang dari $1 / 4$ sebesar $42 \%$ dan untuk kulit yang tersisa lebih dari $1 / 4$ sebesar $14 \%$.

\section{SIMPULAN}

Simpulan yang diperoleh dari hasil penelitian dan pengolahan data mesin pembersih dan pengupas kentang adalah sebagai berikut:

1. Mesin pembersih dan pengupas kentang telah berhasil dibuat, mesin tersebut terdiri dari beberapa komponen yaitu: tabung, sikat, unit transmisi dan rangka, kapasitas dari mesin tersebut yaitu sebesar $60 \mathrm{~kg} / \mathrm{jam}$, dimensi tinggi keseluruhan yaitu $1000 \mathrm{~mm}$, lebar, $400 \mathrm{~mm}$ dan panjang $400 \mathrm{~mm}$.

2. kapasitas aktual mesin pembersih dan pengupas kentang hasil pabrikasi yaitu sebesar $60 \mathrm{~kg} / \mathrm{jam}$, sedangkan kapasitas teoritis sebesar 152 kg/jam, sehingga diperoleh efisiensi mesin pembersih dan pengupas kentang sebesar 57,62\%.

\section{DAFTAR PUSTAKA}

Hall. AS, AR Holowenko and HG Laughin. 1993. Theory and Problem of Machine Design. McGraw-Hill. Singapore.

Harsokoesoemo HD. 1999. Pengantar Perancangan

Teknik. Direktorat Jenderal Pendidikan Tinggi Departemen Pendidikan Nasional. Jakarta.

Keputusan Menteri Negara Lingkungan Hidup Nomor: KEP-49/MENLH/11/1996.

Khurmi, RS and JK Gupta. 2008. A Textbook of Machine Design. S Chand \& Company Ltd. New Delhi.

Peraturan Menteri Tenaga Kerja dan Transmigrasi Nomor. PER. 13/MEN/X.2011.

Shigley. JE. 1986. Perancangan Teknik Mesin jilid 2.

Edisi keempat. Erlangga, Jakarta.

Singer, FL, P Andrew and S Darwin. 1995. Strength of Material (Kekuatan Bahan). Edisi Ketiga Erlangga. Jakarta.

Stefanus, S. 2005. Reverse Engineering - Teori dan Aplikasi, Badan Penerbit Universitas Diponegoro. Semarang.

Sularso dan Suga. 1997. Dasar Perencanaan dan Perancangan Elemen Mesin. Cetakan Kesembilan. Pradnya Paramita. Jakarta. 